\title{
Cell therapy in renal ischemia/reperfusion experimental model using recombinant G-CSF
}

\author{
Vinicius Correa Rodrigues ${ }^{*}$, Isabela Bastos Binotti Araújo ${ }^{1}$, Rosiane Ervati ${ }^{2}$, Sônia da Penha Silva Oliveira ${ }^{2}$, \\ Breno Valentim Nogueira ${ }^{2}$ \\ From 5th Congress of the Brazilian Biotechnology Society (SBBIOTEC) \\ Florianópolis, Brazil. 10-14 November 2013
}

\section{Introduction}

The colony stimulating factor granulocyte (G-CSF) is a glycoprotein capable of promoting the survival, proliferation and differentiation of hematopoietic cells. Studies demonstrate the cytoprotective action of G-CSF against renal injury by ischemia/reperfusion injury in murine models. But the literature is still controversial in relation to the risk of worsening renal function after useG-CSF, which motivated the study to elucidate possible interference on the renal function of the treated animals.

\section{Objective}

Evaluate the renal function of rats after treatment with G-CSF at different doses of the drug.

\section{Methods}

Male Wistar rats $(\mathrm{n}=18), 200 \mathrm{~g}$ approx. (CEUA050/2013), divided into 3 groups (6 animals each) : control group (C) $5 \%$ glucose solution (solvent) groups treated with G-CSF at a dose of 10 (G10) and 50 (G50) $\mathrm{mg} / \mathrm{kg} /$ per 5 days. After treatment, the rats were placed in metabolic cages for urine collection and obtaining urine volume. Values were obtained from creatinine, proteinuria, urea and number of circulating leukocytes. The results were expressed as mean \pm SEM. The averages ofvalues between groups were calculated using one - way ANOVA followed by post hoc Fisher for comparison between differentgroups.

\section{Results}

A significant increase in the number of circulating leukocytes in animals treated with G- CSF (C = 9687 \pm 899 / $\mathrm{mm} 3 ;=14375 \pm 1967 / \mathrm{mm} 3 \mathrm{G} 10$, and G50 = $19670 \pm$ $1663 / \mathrm{mm} 3, \mathrm{p}<0.05)$. There was not a significant increase in urine volume after 24 hours treatment with G-CSF. There was no significant difference between the values of creatinine clearance, proteinuria and Urea, among groups C, G10 and G50.

\section{Conclusion}

There was no impairment of renal function in animals treated at doses of 10 and $50 \mathrm{mg} / \mathrm{kg} /$ per 5 days.

Financial support: FAPES

\section{Authors' details}

'PG Biotecnologia, UFES, Vitoria, Brasil. "2Departamento de Morfologia, UFES, Vitoria, Brasil.

Published: 1 October 2014

\section{References}

1. Stokman G, Leemans JC, Claessen N, Weening JJ, Florquin S: Hematopoietic stem cell mobilization therapy accelerates recovery of renal function independent of stem cell contribution. J Am Soc Nephrol 2005, 16(6):1684-1692.

2. Nishida M, Hamaoka K: How does GCSF act on the kidney during acute tubular injury? Nephron Exp Nephrol 2006, 104(4):e123-e128.

3. Verweij $M$, Sluiter W, van den Engel $S$, Jansen E, lizermans JN, de Bruin RW: Altered Mitochondrial Functioning Induced by Preoperative Fasting May Underlie Protection Against Renal Ischemia/Reperfusion Injury. Journal of Cellular Biochemistry 2013, 114(1):230-237.

doi:10.1186/1753-6561-8-S4-P25

Cite this article as: Rodrigues et al.: Cell therapy in renal ischemia/ reperfusion experimental model using recombinant G-CSF. BMC

Proceedings 2014 8(Suppl 4):P25. 